\title{
The Incubation Mechanism and Incubation Performance Evaluation of "Co-creation Space" in Colleges and Universities
}

\author{
Wei Yaping ${ }^{1,2}$, Liu Shuangyan ${ }^{2}$ \\ ${ }^{1}$ School of Economics and Management, Tiangong University, Tianjin, China \\ ${ }^{2}$ Department of Accounting, Tianjin University of Commerce Boustead College, Tianjin, China \\ Email address: \\ weiyaping@tiangong.edu.cn (Wei Yaping),3040150648@qq.com (Liu Shuangyan)
}

To cite this article:

Wei Yaping, Liu Shuangyan. The Incubation Mechanism and Incubation Performance Evaluation of "Co-creation Space" in Colleges and Universities. Science Journal of Business and Management. Vol. 9, No. 2, 2021, pp. 92-102. doi: 10.11648/j.sjbm.20210902.16

Received: May 15, 2021; Accepted: May 30, 2021; Published: June 21, 2021

\begin{abstract}
The construction of "co-creation space" in colleges and universities has created a comprehensive support platform for their students to start their own businesses, and plays an important role in implementing the innovation-driven development strategy of the country. However, china's " co-creation space " in colleges and universities started relatively late, the law of business incubation has not yet been clarified, the entrepreneurship incubation mechanism, performance evaluation and other research is relatively weak, indirectly affecting the practice of innovation and entrepreneurship guidance. The purpose of this paper is, through the study of the incubation mechanism and performance evaluation of the university's co-creation space, to provide some reference for better use of the superior resources of colleges and universities to improve the incubation efficiency and improve the quality of the incubation of the "co-creation space". This paper analyzes the meaning of " co-creation space " and the function of incubation service in colleges and universities, and expounds the mechanism of the incubation capacity of the university's creation space, that is, the cultivation mechanism of the spirit of creation, the nesting mechanism of the entrepreneurial network, the mechanism of heterogeneous synergy of entrepreneurship, the mechanism of upgrading the incubation capacity and the interrelated role between them. Based on the meaning of the incubation mechanism of "university co-creation space", the influence factors of incubation performance are extracted, and the evaluation index system of incubation performance of "creation space" in colleges and universities is constructed on this basis. And designed a set of operational evaluation procedures. Data sources are obtained by means of questionnaires and interviews, respectively. using the scoring method of Licht's five-point scale, the incubation performance of selected case universities was tested and evaluated, the evaluation scores were obtained, and the corresponding evaluation results were determined by reference to other evaluation criteria. Reasonable suggestions are put forward for the problems found in the evaluation.
\end{abstract}

Keywords: "Co-creation Space", Incubation Mechanism, Incubation Performance, Evaluation

\section{Introduction}

Universities are an important combination of scientific and technological productivity and talent resources. The construction of "Co-creation space" in Colleges and Universities, give full play to the advantages of college talents and scientific research, for college students to create a comprehensive entrepreneurial support platform, "Learning, practice, competition, research, innovation and entrepreneurship" is the five gradual processes of college students' innovation and entrepreneurship activities, which can be called the "five-level pyramid training system" of innovation and entrepreneurship [1], all of which can be realized in the university's co-creation space. The co-creation space integrate innovative entrepreneurial ideas and practices into the whole process of cultivation, and builds the growth path of "creative-innovation-entrepreneurship", which becomes the main position of college students' innovation and entrepreneurship and employment practice [2]. The co-creation space has played an important role in implementing the innovation-driven development strategy of the state, deepening the reform of innovation and entrepreneurship education in colleges and universities, and 
building an innovative country [3].

The incubation effect of the "Co-creation space" is an important embodiment of the creator's transformation of whimsy into real productivity. However, it is undeniable that because of the late start of the "Co-creation space" in China, the training experience of the university students' innovation and entrepreneurship projects is insufficient, the incubation law of the "co-creation space" has not been clarified, there is a disconnect between the transformation of entrepreneurial achievements within the creation space and the needs of the market, which can't meet the urgent needs of social enterprises [4], the hatching effect is uneven, and the incubation performance evaluation system is not perfect. At present, the academic circles have made many useful explorations on the mode of operation of the university's co-co-creation space, mainly focusing on the development mode, meaning, function, construction countermeasures and so on, but the research on the operation mechanism and performance evaluation of the university's mass co-creation space is relatively weak, which indirectly affects the guidance of innovation and entrepreneurship practice. Therefore, this paper carries on the research of the incubation mechanism and incubation performance evaluation of the "Co-creation space", in order to provide some reference for using the superior resources of the university to improve the incubation efficiency and improve the quality of the operation of the "Co-creation space".

\section{A Review of the Literature on the Function and Incubation Evaluation of the Co-creation Space}

The prototype of the" co-creation space" is an incubator, which Hansen M T. [5] interprets as a professional organization that provides incubation support (places and services) to growing start- ups. Their rise is the result of many entrepreneurial activities and incubator innovations in the era of knowledge economy. On the basis of incubators, the co-creation space can be formed and accelerated.

Isenberg.[6] from the perspective of the sharing economy, the creation of the creator space in the hardware, software and cooperation and other elements to create a unique pattern of behavior of the creators. Through the study of the space ecosystem of co-creation space, a group of American scholars headed by Vogel.[7] found that their service path includes cross-border, shared creative education: providing low-cost, one-stop crowdsourcing services: building connected, interactive and innovative service platforms. Through the study of the co-co-creation space under the innovation 2.0 mode, Lin Song.[8] puts forward the functional model of the co-co-creation space, and summarizes the corresponding operation mode and service path. For the increasingly demonstrated entrepreneurial incubation function of the crowd-creating space, Wang Youshuang.[9] believes that the incubation ability is the core ability of the co-creation space, and divides the incubation ability from the horizontal and vertical dimensions.

From the development of incubation capacity to the need for the evaluation of the performance of incubation in the co-creation space, and there are different types of detailed research. Peng Zhansheng and Li Rongjun [10], have conducted an evaluation and study on the incubation performance of China's science and technology enterprises' co-creation space, and believe that the incubation results of China's science and technology enterprises are in a steady upward trend. Cai Xiaolin [11] evaluates the incubation performance of social co-creation space from four aspects: service ability, operational level, incubation efficiency and social contribution. For the evaluation of the incubation function of the university's co-creation space, Sarfraz A. Mian.[12] established the performance evaluation system of the university's science and technology enterprise incubator, including the sustainability and growth of the project, the competitiveness and growth of the incubation enterprise, and the contribution of the start-up mission. Wu Junze and Tang Houxing [13] constructed the evaluation index system from the perspective of the positioning of the spatial function of the creation space, combined with the characteristics and purposes of the "double creation" education in colleges and universities. Through field research, Li Zhengwei [14] systematically constructed a comprehensive evaluation model of the performance of the space-generated space in higher vocational colleges and analyzed it. In addition, Tian Zhongliang [15], Xue Ting [16], Feng Yu-ye [17] and so on have focused on the "co-creation space" performance evaluation indicators construction has been studied.

From the above point of view, the overall incubation mechanism and law of the co-creation space, relatively perfect is the "social enterprise co-co-co-creation space". Based on the characteristics of colleges and universities, the research on the incubation mechanism and effectiveness of the "co-creation space" is relatively small, and it focuses on the qualitative exposition of functions and the construction of the index system, most of which stop at the actual evaluation after the construction of the index system. Because the core of "cultivating people" in colleges and universities is fundamentally different from the core of "profit" in social enterprises, it is difficult for many research results of enterprise-type co-creation space to be applied directly to colleges and universities. In view of this defect, this paper carries out research from the chain about incubation mechanism of the university's co-creation space - incubation performance evaluation - implement the application, in order to make up for some of the shortcomings of the current research.

\section{The Mechanism of Incubation Capacity of the "Co-creation Space"}

Co-creation space provides entrepreneurs with workspace, cyberspace, social space and resource sharing space, and is a complex entrepreneurial system formed by the concentration 
of many entrepreneurial activities in a particular geographical space [18]. The unity of correlation and interaction between college students-maker, fund providers, social intermediary institutions and university administrative departments, with the creation of space as the carrier, jointly practice the whole process of innovation and entrepreneurship, and thus form a unique mechanism for the incubation of Co-creation space entrepreneurship. That is, the cultivation mechanism of the spirit of creation, the nesting mechanism of the entrepreneurial network, the mechanism of heterogeneous coordination of entrepreneurship, the mechanism of incubation capacity enhancement [19]. These four mechanisms are closely related and interact with each other, reflecting the inherent law of the incubation mechanism of the Co-creation space entrepreneurship. The incubation mechanism is shown in Figure 1.

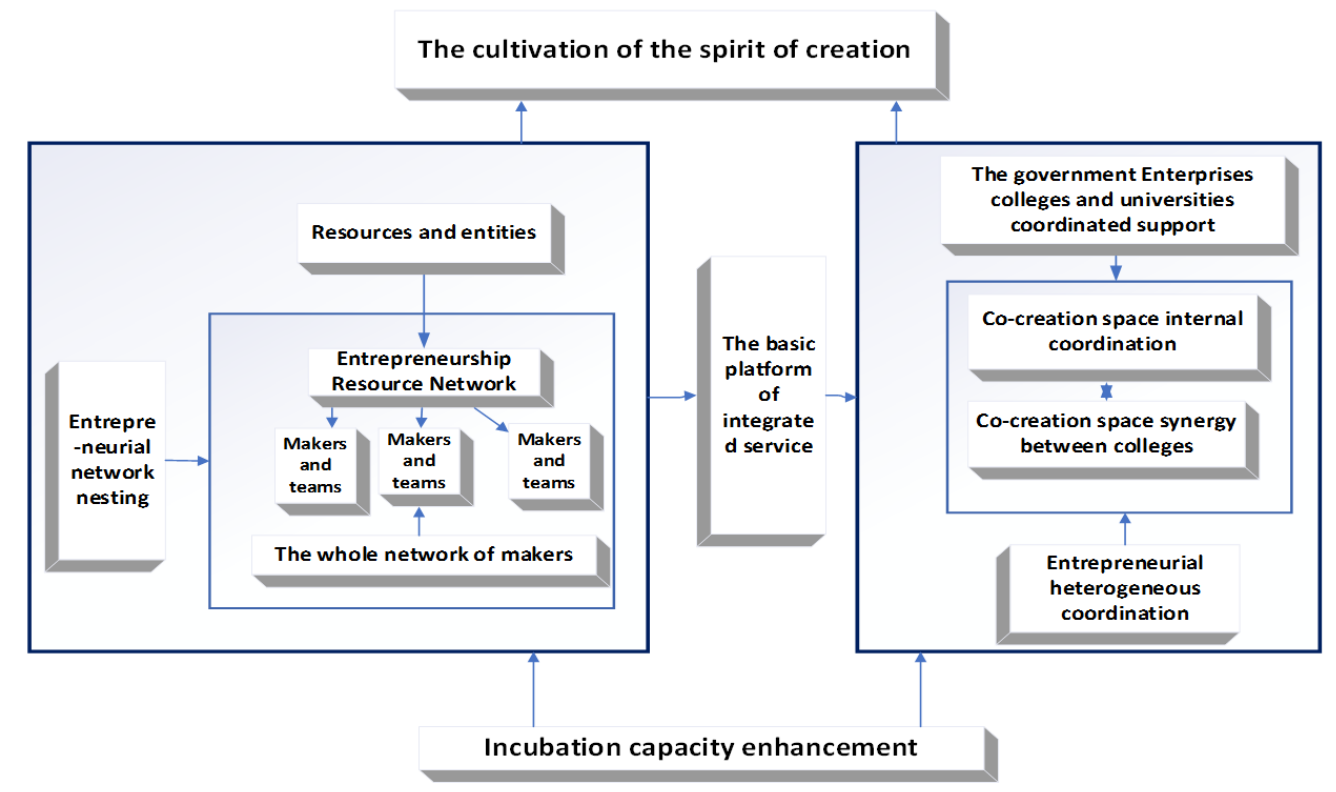

Figure 1. Map of the incubation mechanism of the university's co-creation space entrepreneurship.

\subsection{The Cultivation Mechanism of the Spirit of Creation}

The construction of the space of mass creation in colleges and universities is focused on the construction of spirit, the goal is to lay the foundation of thought and action skills for college students to start their own businesses. Therefore, the cultivation mechanism of the spirit of co-creation should be to complete the whole process from project conception, planning, simulation to operational implementation. In the atmosphere of the university's co-creation space, college students can realize the rich connotation and true meaning of entrepreneurship through entrepreneurship conception and entrepreneurship planning and entrepreneurship drills until they are finally put into action.

\subsection{Entrepreneurial Network Nesting Mechanism}

Many college students' creators and entrepreneurial resources in the co-creation space, weaving into a crisscrossing, nested network connection, is the organization of the co-creation space, more conducive to the absorption of new knowledge, the formation of creativity and exploratory innovation. Network nesting is divided into two levels:

i. "M-bit creator-M-bit creator" style network connection. The network connection between the creators by means of information exchange, knowledge sharing, spiritual transmission and business dealings is applicable to create a free exploration atmosphere in the co-creation space.

ii. "N-bit resource main body-N-bit creator" style creator network. The network connection focuses on the initial release, implementation, and docking of external resources for the potential value of the idea. The main body of entrepreneurial resources is related to each other and forms the network of entrepreneurial resources, which is the most important link of the space of mass creation.

\subsection{Entrepreneurial Heterogeneous Coordination Mechanism}

Entrepreneurial heterogeneous coordination mechanism is a mechanism of mutual assistance and mutual integration, which is formed by cooperation between schools and enterprises through cooperation between schools and enterprises in all links of the innovation and entrepreneurship chain, and cooperation with heterogeneous resources inside and outside the school [20]. The whole-element resource integration ability and the whole chain entrepreneurial service ability formed by this mechanism are the most urgently needed key capabilities of the university's co-creation space. Through the heterogeneous coordination mechanism of entrepreneurship, the joint advantages promote the innovation and entrepreneurship of college students, and promote the upgrading of innovative entrepreneurship platform services. 


\subsection{Incubation Capacity Enhancement Mechanism}

Incubation capacity enhancement mechanism is based on the good operation of the first three mechanisms, providing incubation function and enhancement function, in order to help create the realization of the vision of space objectives, and therefore also become the key mechanism of the whole process of co-creation space services. Specifically, the university's co-creation space provides physical space, supporting facilities and entrepreneurial support, relying on the advantages of the university's technical resources, the high-tech projects will be packaged and hatched into a technology and products with independent intellectual property rights. Reduce the risk of entrepreneurship, in order to go to the real entrepreneurial path.

The above mechanism takes the cultivation of the spirit of public creation as the starting point, forms a higher level of entrepreneurial quality, then the effect of radiation to the whole system below. Take the "network" as a self-organization and borderless intermediate organization form, through the creator-team-resource horizontal network connection, the formation of entrepreneurial network nesting mechanism; The module in the middle is the basic platform of integrated service, which plays the function of integrating with heterogeneous resources inside and outside the school and the whole chain service, that is, the mechanism of entrepreneurship heterogeneous coordination. The three mechanisms are integrated to enhance the incubation capacity.

\section{Evaluation of the Performance of Incubation in the Co-creation Space of Colleges and Universities}

\subsection{The Construction of the Performance Evaluation System of the Incubation of the University's Co-creation Space}

The evaluation of the incubation performance of the co-created space is a kind of special evaluation of the incubation ability of the co-creation space, in order to show the incubation results and performance. To the design of the incubation performance evaluation system of the university's co-creation space, the factors influencing the incubation performance are first refined, and the framework of the evaluation index system is constructed accordingly. Secondly, through the questionnaire test to determine the weight of indicators, and finally form an incubation performance evaluation system, so that can effectively improve the objectivity and professionalism of the evaluation system [10].

\subsubsection{Incubation Performance Influence Factors}

The refinement of the influencing factors of incubation performance is guided by the meaning of " The mechanism of incubation capacity of the"co-creation space", and also is based on expert interviews, field research, literature study and so on, including basic service capacity, creative spirit cultivation ability, gathering innovation and entrepreneurial ability, value-added service capacity and sustainable development capacity.

\section{i. Basic service capacity}

Co-created space provides basic services by providing a field platform in the space that integrates the needs of the incubating enterprise, including the size of the space provided, open shared office space (number of jobs), hardware and software development platform, catering, apartments and other hardware facilities. Basic service function is an important evaluation factor of the incubation performance of the co-creation space, and good infrastructure can reduce the start-up cost of the start-up team.

ii. Cultivation of creative capacity

The cultivation of the ability of mass creation is accomplished through basic education and entrepreneurship exercises. Basic education is formed through the combination of entrepreneurship courses, forming the framework of students' entrepreneurship knowledge reserve. Entrepreneurship drills are divided into two links, entrepreneurship training and entrepreneurial experience [21], entrepreneurship training through simulation of practical activities, enhance the emotional understanding of starting a business; Entrepreneurial experience relies on the open environment of the co-creation space, the development of innovative entrepreneurship training projects to experience entrepreneurial practice.

iii. Gather innovative entrepreneurial capacity

Gathering innovation and entrepreneurial ability reflects the ability of co-creation space to attract talents, and the reserve of talents is the first condition for innovation and entrepreneurship. Attracting in-house creators, entrepreneurial team presence and entrepreneurial team registration are important factors influencing incubation performance.

iv. Value-added service function

Through the gathering of creators, the co-creation space creates a service atmosphere of mutual communication, thought collision, experience exchange and resource sharing, which can effectively promote the development process of enterprises or projects. Many project founders are also attracted by the service atmosphere created by the co-creation space. Therefore, the value-added service function of co-creating space is an important factor influencing incubation performance.

v. Organizational structure and management capabilities

Co-creation space brings together different kinds of enterprise or project teams, so it is necessary for it to have a good set of operational and management mechanisms. The management ability of the Co-creation space, especially the level of competence of senior management is a direct manifestation of the improvement of the operational capabilities of the space, a good organizational structure is the key to good management ability. Together, they affect the incubation performance of the co-creation space.

vi. Sustainable development capacity

Refers to the Co-creation space through self-management ability and comprehensive strength to enhance the innovative 
operating model, and continuously improve the ability and level of innovative entrepreneurial services. The most intuitive embodiment is the strength of the space assets and incubation results of the state: including the degree of transformation of scientific and technological achievements and the commercial transformation of incubated enterprises, it is the main manifestation of the output of the operation of the Co-creation space, and is the result of the university's "sleeping" patents and inventions are awakened [22]. It embodies the conditions and possibilities for the sustainable development of co-creation space.

\subsubsection{Incubation Performance Indicator System and Meaning}

Through the analysis of incubation mechanism and the influencing factors of incubation performance, and following the principles of objectivity, operability and goal professional orientation of index design, the framework of evaluation index system can be constructed. The indicator system and meaning are shown in Table 1.

Table 1. System and meaning of performance evaluation index of incubation in the co-creative space.

\begin{tabular}{|c|c|c|}
\hline Factors & Index & Meaning \\
\hline \multirow{3}{*}{$\begin{array}{l}\text { Basic service } \\
\text { capacity }\end{array}$} & 1. Total area of co-creation space & Refers to the sum of offices, laboratories, and shared area \\
\hline & 2. Total number of seats available & Total number of seats available for incubating teams and enterprises \\
\hline & 3. Infrastructure input & vestment in shared facilities, laboratories and communication networks \\
\hline \multirow{2}{*}{$\begin{array}{l}\text { Cultivation of } \\
\text { creative capacity }\end{array}$} & 4. Entrepreneurship education & to carry out the number of courses to accept innovative entrepreneurship \\
\hline & 5. Entrepreneurship exercise status & $\begin{array}{l}\text { Participated in team building, mentor guidance, project training, discipline } \\
\text { competitions and other activities to gather innovative entrepreneurial ability }\end{array}$ \\
\hline \multirow{2}{*}{$\begin{array}{l}\text { Gather innovative } \\
\text { entrepreneurial } \\
\text { capacity }\end{array}$} & 6. Innovationand entrepreneurship mentor team & Number of innovative entrepreneurship mentors \\
\hline & 8. The cumulative number of incubated items & $\begin{array}{l}\text { The number of incubating enterprises or projects accumulated since the } \\
\text { establishment of co-creation space }\end{array}$ \\
\hline \multirow{3}{*}{$\begin{array}{l}\text { Value-added } \\
\text { service capacity }\end{array}$} & $\begin{array}{l}\text { 9. The effect of carrying out various kinds of } \\
\text { innovative activities }\end{array}$ & $\begin{array}{l}\text { Refers to the number of incubating enterprises to participate in entrepreneurship and } \\
\text { training activities. }\end{array}$ \\
\hline & 10. Contracted cooperative institutions & $\begin{array}{l}\text { refer to the number of cooperative service institutions, reflecting the intermediary } \\
\text { capacity of space. }\end{array}$ \\
\hline & 12. The status of school-enterprise cooperation & $\begin{array}{l}\text { Number of school-enterprise cooperation exchanges Organization and management } \\
\text { capacity }\end{array}$ \\
\hline \multirow{2}{*}{$\begin{array}{l}\text { Organizational } \\
\text { structure and } \\
\text { management } \\
\text { capabilities }\end{array}$} & 13. Talent quality structure & $\begin{array}{l}\text { The academic qualifications and professional structure of the space managers of the } \\
\text { public creation. }\end{array}$ \\
\hline & 14. Organizational structure & $\begin{array}{l}\text { refers to the rationality of the structure of the co-creation space management } \\
\text { organization Sustainable development capacity }\end{array}$ \\
\hline \multirow{2}{*}{$\begin{array}{l}\text { sustainable } \\
\text { development } \\
\text { capacity }\end{array}$} & $\begin{array}{l}\text { 15. Number of patents granted by incubating } \\
\text { enterprise team }\end{array}$ & $\begin{array}{l}\text { refers to the number of patents obtained by an enterprise or team, reflecting the } \\
\text { results of incubation }\end{array}$ \\
\hline & 16. Number of successfully hatched enterprises & refers to the number of business enterprises that have hatched entrepreneurial teams. \\
\hline
\end{tabular}

\subsection{Survey by Questionnaire}

\subsubsection{Survey of Index Weight}

After constructing the index system, the index weight determination basis is obtained through the questionnaire. The questionnaire was aimed at 20 relevant experts, people-created space leaders and some entrepreneurs. The questionnaire is detailed in Appendix 1: Questionnaire on the importance of the incubation performance evaluation indicators for co-creative space. According to the questionnaire, the Importance of the evaluation index of the popular space incubation index is rated, the average score of each index is calculated, and the weight of the corresponding index is obtained, see Table 2.

Table 2. Scores and weights on the importance of the co-creative space Incubation Performance Evaluation Indicators.

\begin{tabular}{|c|c|c|c|c|}
\hline order number & index (A) & data type & Average score (B) & Weights (D) \\
\hline 1 & Total area of co-creation space & Licht's five-point scale & 2.8250 & 0.0469 \\
\hline 2 & Total number of seats available & Licht's five-point scale & 4.0750 & 0.0677 \\
\hline 4 & Entrepreneurship education & Licht's five-point scale & 3.0750 & 0.0511 \\
\hline 5 & Entrepreneurship exercise status & Licht's five-point scale & 4.3125 & 0.0716 \\
\hline 6 & Number of innovative and entrepreneurial mentors & Licht's five-point scale & 3.5875 & 0.0596 \\
\hline 8 & The cumulative number of incubated items & Licht's five-point scale & 3.0750 & 0.0511 \\
\hline 9 & The effect of carrying out various kinds of innovative activities & Licht's five-point scale & 2.1375 & 0.0355 \\
\hline 10 & Number of contracted cooperative institutions & Licht's five-point scale & 4.6375 & 0.0770 \\
\hline 11 & Total amount of financing for the resident enterprise team & Licht's five-point scale & 4.5250 & 0.0752 \\
\hline
\end{tabular}




\begin{tabular}{|c|c|c|c|c|}
\hline order number & index $(A)$ & data type & Average score (B) & Weights (D) \\
\hline 12 & The status of school-enterprise cooperation & Licht's five-point scale & 2.2500 & 0.0374 \\
\hline 13 & Talent quality structure & Licht's five-point scale & 3.0625 & 0.0509 \\
\hline 14 & Organizational structure & Licht's five-point scale & 2.7250 & 0.0453 \\
\hline 15 & Number of patents granted by incubating enterprise team & Licht's five-point scale & 4.0625 & 0.0675 \\
\hline 16 & Number of successfully hatched enterprises & Licht's five-point scale & 4.5250 & 0.0752 \\
\hline 17 & Policy grants & Licht's five-point scale & 3.7250 & 0.0619 \\
\hline
\end{tabular}

among: Average score of the indicator $=\frac{\text { The sum of questionnaire fill-ins for each questionnaire score of the indicator }}{\text { Number of copies filled out in the questionnaire }}$

Weights $=\frac{\text { Average score of individual indicators }}{\text { Average score of all indicators }} \times 100 \%$

Average score of all indicators $=\sum_{\mathrm{i}=1}^{18} \mathrm{Bi}=60.2000$

Take the " Total area of co-creation space " indicator as an example,

Average score of the indicator $=2.8250, \quad$ weight $=\frac{2.8250}{60.2000} * 100 \%=4.69 \%$

The remaining indicator weights are calculated as the same.

\subsubsection{The Implementation of Questionnaires and Interviews}

After determining the index weight for the incubation performance evaluation index system of the co-creation space, all the indicators are divided into two categories according to the source of the data obtained: one is to obtain the data through the incubation enterprise questionnaire, referred to as the questionnaire evaluation; One is to obtain data through the co-creation space management interviews, referred to as interview evaluation. All the evaluation data obtained were based on the Licht five-point scale, which assigned 1, 2, 3, 4, 5 grades to the answers to the questions in the questionnaire, of which: 1, 2 were considered a category, indicating that the evaluation was "no"; 4, 5 is considered to be a category that indicates that the evaluation is "yes"; 3 indicates "moderate" and is accompanied by an mean (the maximum value is 5) to reflect the average state of the sample. (because the interview evaluation data have no mean, the interview data can be used directly as a sample status)

The object of the questionnaire is the resident enterprise of the co-creation space of a science and engineering colleges and universities in Tianjin city, a municipality directly under the Central Government of China. Because there are few cases in practice that can be used for reference, our evaluation is of a test nature, the questionnaire sample is relatively small, a total of 27 , the recovery questionnaire is all valid questionnaire. Then the valid questionnaire was entered and processed by EXCEL software.

\subsection{Incubation Performance Evaluation}

\subsubsection{Incubation Performance Questionnaire Evaluation}

The questionnaire evaluation obtains the data by distributing the questionnaire to the head of the co-creation space incubation enterprise or team (see Appendix 2 "Survey on the incubation of the university's co-creation space business"), and the data type is Licht's five-point scale. The average score is obtained according to the questionnaire data, and the final evaluation score is calculated according to the weight of the indicator. See table 3.

Table 3. Questionnaire Evaluation Indicator Score List.

\begin{tabular}{|c|c|c|c|c|}
\hline order number & index $\left(A_{2}\right)$ & $\begin{array}{l}\text { Average score } \\
\text { (H) }\end{array}$ & weights (D) & $\begin{array}{l}\text { Weighted average } \\
\text { score }(\mathrm{F})\end{array}$ \\
\hline 1 & Infrastructure input & 4.0750 & 0.0667 & 0.2718 \\
\hline 2 & Entrepreneurship education & 4.0125 & 0.0511 & 0.2050 \\
\hline 3 & Entrepreneurship exercise status & 3.0750 & 0.0716 & 0.2202 \\
\hline 4 & Number of entrepreneurial teams and businesses absorb employment & 4.3125 & 0.0596 & 0.2570 \\
\hline 5 & The effect of carrying out various kinds of innovative activities & 3.5875 & 0.0355 & 0.1274 \\
\hline 6 & The status of school-enterprise cooperation & 3.1375 & 0.0374 & 0.1173 \\
\hline 8 & Number of patents granted by incubating enterprise team & 2.4375 & 0.0675 & 0.1645 \\
\hline Amounts & & - & - & 1.5733 \\
\hline
\end{tabular}

As can be seen from the above calculations, the total score of the questionnaire evaluation

$$
\mathrm{F}==\sum_{i=1}^{8} H_{i} \times D_{i}=1.5733
$$

\subsubsection{Incubation Performance Interview Evaluation}

Interview evaluation is obtained through field interviews with the management of co-creation space (see Appendix 3, "An outline of interviews on the incubation of public 
co-creation space in colleges and universities"), such indicators examine the level of operation and management of co-creation space as the main operating body, enterprises and teams, as the constituent units in space, are not the same operating body as the co-creation space itself, so it is necessary to conduct separate interviews with the space management. Based on the interview data, the assignment data are determined (see Appendix 4,"The interview data assignment table for the incubation of university's co-creation space start-ups"), and the data type is Licht's five-point scale. The final evaluation score is then calculated according to the weight of the indicator. See table 4 [23].

Table 4. Interview Evaluation Indicator Score List.

\begin{tabular}{|c|c|c|c|c|c|}
\hline order number & index $\left(A_{2}\right)$ & Interview data & Data score $(\mathrm{E})$ & Index weight (D) & Weighted average score $(\mathrm{L})$ \\
\hline 1 & Total area of co-creation space & $1500 \mathrm{~m}^{2}$ & 4 & 0.0469 & 0.1876 \\
\hline 2 & Total number of seats available & 68 & 3 & 0.0677 & 0.2031 \\
\hline 3 & Number of innovative and entrepreneurial mentors & 16 & 4 & 0.0596 & 0.2384 \\
\hline 4 & The cumulative number of incubated items & 68 & 4 & 0.0511 & 0.2044 \\
\hline 5 & Number of contracted cooperative institutions & 15 & 4 & 0.0770 & 0.3080 \\
\hline 6 & Total financing for resident enterprise teams ( $¥ 10,000$ ) & 60 & 5 & 0.0752 & 0.3760 \\
\hline 7 & Talent quality structure (undergraduate ratio) & $100 \%$ & 5 & 0.0509 & 0.2545 \\
\hline 9 & Policy Grant Fund $(¥ 10,000)$ & 100 & 5 & 0.0619 & 0.3095 \\
\hline Amounts & & & & - & 2.3823 \\
\hline
\end{tabular}

As can be seen from the above calculations, the total score of the interview evaluation

$$
\mathrm{L}==\sum_{i=1}^{9} E_{i} \times D_{i}=2.3823
$$

\subsubsection{A general Evaluation of the Incubation Performance of Co-creation Space in Case Colleges and Universities}

i. Add the total score to determine the evaluation grade

By adding the two parts of the case university's co-creation space performance evaluation score, we can get the evaluation score according to Licht's five-point scale, so as to determine the evaluation grade. That is:

The total score of the performance evaluation of the co-creation space in the case university (Q)

$=$ the total score of the questionnaire evaluation $(\mathrm{F})+$ the total score of the interview evaluation (L)
$=1.5733+2.3823=3.9556$

The maximum score of the Licht's five-point scale evaluation standard is 5 points, with an average of 3 points. The total score of this evaluation is 3.9556 points, indicating that the case of universities' creation space incubation performance has been nearly good.

ii. Refer to the relevant literature as a reference criterion for performance evaluation

In order to further determine the evaluation results, reference may be made to the relevant literature on the national incubation base of the incubation performance evaluation rating research, as the evaluation grade of this case to determine the reference criteria, in order to further assess the case of the university's incubation performance. The national incubation performance ratings that can be referred to are shown in Table 5:

Table 5. Incubate Performance Appraisal Metrics Hierarchy.

\begin{tabular}{llll}
\hline order number & Hierarchy & score for the grade & Strategic choice \\
\hline 1 & excellen & $85-100$ (Above 85$)$ & Keep it up \\
2 & good & $75-85$ (Above 75) & General optimization \\
3 & pass muster & $60-75$ & Partial improvement \\
4 & below grade & Below 60 & Large scale improvement \\
\hline
\end{tabular}

Source: Liang Lin, Liu Xiantao. Design of the index system for incubation capacity evaluation of business incubators based on incubation functions. Technology and Management, 2015 (4): 28-30.

Referring to the evaluation index scale, in order to facilitate comparison, the total evaluation score represented by the Licht's five-point scale of the case is converted to a percentage system. That is, the original score of 3.9556 points to 79.11 points $\left(3.9556 \mathrm{x} \frac{100}{5}=79.11\right)$, the conversion of the corresponding grade is "good", consistent with the evaluation grade calculated by the five-point scale.

In addition, according to Xiao Zhixiong, Wang Ran [24] on the domestic "Double first-class" university's co-creation space survey made a general conclusion, think that "double first-class" university level of the overall quality of the co-creation space is relatively good, and this case also belongs to the double first-class university co-creation space, indirectly indicating that the case in the country belongs to a good series.

To sum up, this case of the basic service capacity has been more perfect, the organization structure is complete, the management ability is also constantly improving, especially actively building intelligent information platform, building the creator space intelligent service system, to achieve "innovation and entrepreneurial knowledge a little pass", is a unique value-added service. However, capacity for sustainable development needs to be strengthened 


\section{Problems and Suggestions for Improving Them}

\subsection{The Problems in the Incubation Performance of the University's Co-creation Space}

Through the test evaluation of the case, as well as the initial understanding of the performance of the national university's co-creation space, found that there are the following problems:

i. the ability of co-creation space value-added services is not sufficient. Failure to fully reflect the core advantages of the school's discipline characteristics, to provide entrepreneurial value-added services varying levels. Its activities are single in content and form, generally only according to the setting of the subject, not according to the needs of students, it is difficult to fully meet the diverse needs of entrepreneurial teams, limiting the incubation capacity of the co-creation space.

ii. The profitability of co-creation space is weak. Their benefit mainly comes from government subsidies, and the opening of the co-creation space in colleges and universities belongs to the nature of public welfare education, which ranks the profit side after the students' ability training. In addition, some colleges and universities have the minimum protection policy of entrepreneurship failure, so the entrepreneurial team project is not very competitive, affecting the incubation performance of the university's creative space.

\subsection{Countermeasures to Improve Incubation Performance}

In view of the inadequate ability of university's co-creation space value-added services, in the process of creating and developing creation space, we should follow the principle of gradual progress, pay attention to collecting the needs of creators, so that they can participate in every step of the creation of creative space, to meet the needs of students' innovation, creativity and so on, to provide excellent services for them. At the same time, in order to promote the university's creation space to continuously expand service functions, the creation space itself should also constantly improve the professional incubation platform, building a professional management team that can support the development of crowd-created space.

In view of the weak profitability of university's co-creation space, we should try our best to improve the profitability of incubated projects, so as to drive the profitability of university's co-creation space. However, the university and society are different, the purpose of the university-type creation space is not mainly to make a profit, more is to cultivate students' innovation and management ability. So for educational purposes, to grasp well the "degree" between profitability experience and entrepreneurial spirit cultivation, to prevent bias.

\section{Conclusions and Comments}

The construction of the "university's co-creation space" has created a comprehensive support platform for college students, which is followed by the concern for the evaluation of the performance evaluation of the incubation of the university's creation space. However, due to the late start of the university's creation space, the research on incubation mechanism, performance evaluation and so on is relatively weak [25]. The research is relatively perfect is the social enterprise co-creation space, but the enterprise-type co-creation space many research results can be directly applied to colleges and universities? People have doubts.

In view of this situation, this paper draws on the experience of enterprise-type co-creation space, starts with the study of the mechanism of enterprise-created space business incubation in colleges and universities, discovers the law of incubation performance generation, evaluates incubation performance on this basis, and embodies the relatively complete research chain of "incubation mechanism-incubation performance evaluation-implementation application".

The entrepreneurship incubation mechanism of the university's creation space is the incubation capacity mechanism, including the cultivation mechanism of the spirit of the crowd-creation, the nesting mechanism of the entrepreneurial network, the mechanism of the heterogeneous synergy of the entrepreneurship, and the mechanism of the enhancement of the incubation ability, which have interrelated effects. Based on the meaning of the business incubation mechanism, the factors affecting incubation performance are extracted, including basic service ability, creative ability cultivation, gathering innovation entrepreneurship ability, value-added service function, organizational structure and management ability and sustainable development ability. On the basis of mechanism guidance and factor condensation, the system of incubation performance evaluation index of "creation space" in colleges and universities is constructed [26].

The incubation performance evaluation procedure is designed, and the evaluation is divided into two categories according to the data source of the index: the questionnaire evaluation of the incubation enterprise; The interview evaluation of the managers of creation space is based on The Licht's Five-Point Scale of for evaluation rating, and the total score is added, which makes the incubation performance evaluation process operable. Then take a big city science and engineering college as the case object, according to the above evaluation procedure, the incubation performance was tested and evaluated, and the corresponding evaluation results were determined by reference to other evaluation criteria, that is, the incubation performance is close to good. At this point, the research chain of "incubation mechanism-incubation performance evaluation-implementation application" has been completed, which makes up for the shortcomings of previous research.

In view of the evaluation results of case tests and the preliminary understanding of the incubation of the national representative university's creation space, the common problems 
are found and the rationalization proposal is put forward: to promote the continuous expansion of the service function of the university's creation space, and to build a professional management team to support the development of the creation space; In order to improve the profitability of incubated projects to drive the profitability of colleges and universities.

The incubation performance evaluation of this paper belongs to the test evaluation, the same kind of research is rare, lack of reference. The Licht's scale used to evaluate assignment methods has inherent flaws in the processing of hierarchical variables, that is, the value of hierarchical variables does not represent the size of variables, only the different levels. In further studies in the future, if more accurate and objective data can be obtained, more reasonable statistical methods can be adopted to carry out more detailed and in-depth research.

\section{Appendix}

\section{Appendix 1: Questionnaire on the Importance of Performance Evaluation Indicators of the Creation Space Incubation}

Please check the degree of impact of the following indicators on the incubation performance of the creation space (the total number of ticks for each column shall not exceed 6):

Table 6. Score Table for the Importance of Performance Evaluation Indicators of the Co-creation Space Incubation.

\begin{tabular}{|c|c|c|c|c|c|c|}
\hline $\begin{array}{l}\text { The serial } \\
\text { number }\end{array}$ & indicators & $\begin{array}{l}\text { Huge impact } \\
\text { (5 points) }\end{array}$ & $\begin{array}{l}\text { Large } \\
\text { influence } \\
\text { (4 points) }\end{array}$ & $\begin{array}{l}\text { General } \\
\text { effect } \\
\text { ( } 3 \text { points) }\end{array}$ & $\begin{array}{l}\text { Less affected } \\
\text { (2 points) }\end{array}$ & $\begin{array}{l}\text { Does not } \\
\text { affect } \\
\text { (1 points) }\end{array}$ \\
\hline 1 & Total area of mass innovation space & & & & & \\
\hline 2 & Total number of stations provided & & & & & \\
\hline 3 & Infrastructure investment & & & & & \\
\hline 4 & The development of entrepreneurship education & & & & & \\
\hline 5 & Status of Entrepreneurship Exercises & & & & & \\
\hline 6 & Innovation and entrepreneurship mentor team & & & & & \\
\hline 7 & Employment number & & & & & \\
\hline 8 & Effects of carrying out all kinds of innovative activities & & & & & \\
\hline 9 & Signed Cooperation Agency & & & & & \\
\hline 10 & Total amount of financing for the settled enterprise team & & & & & \\
\hline 11 & School-enterprise cooperation & & & & & \\
\hline 12 & Talent quality structure & & & & & \\
\hline 14 & Total assets of Maker Space & & & & & \\
\hline 15 & Number of patents approved by incubated enterprise teams & & & & & \\
\hline 16 & Number of successful incubators & & & & & \\
\hline 17 & Policy subsidy & & & & & \\
\hline
\end{tabular}

\section{Appendix 2: Questionnaire Survey on Entrepreneurship Incubation of University the Creation Space}

1. How about the infrastructure investment and service platform construction of the creation space where you are working?

Table 7. Qualitative Index Rating Table.

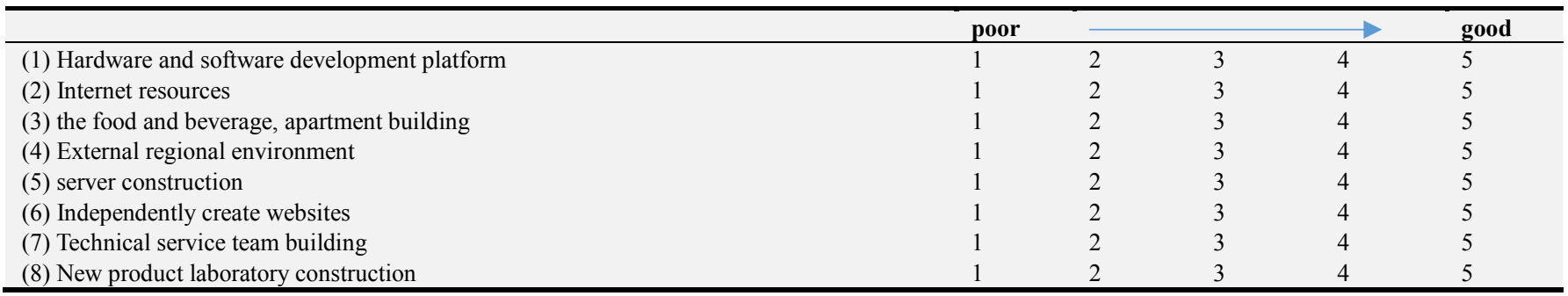

2. How many innovation and entrepreneurship courses has your team participated in?
A. $0-3$
B. 4-6
C. $6-8$
D. $8-10$
E. More than 10

3. What is the total number of times that your team has participated in various entrepreneurial exercises held by Maker Space? (Various innovative activities including team building, mentor guidance, project training, discipline competition, etc.) (Unit: times)
A. 2-4
B. $4-6$
C. 6-8
D. $8-10$
E. More than 10 
4. How many jobs did your start-up team employ?
A. $2-4$
B. 4-6
C. 6-8
D. $8-10$
E. More than 10 times

5. How many times did your team participate in all kinds of innovation activities held by the creation space (All kinds of innovative activities include skills training, professional lectures, team building, resource docking, industry communication, investment negotiation) (Repeat counting) (Unit: times)
A. 2-4
B. 4-6
C. 6-8
D. $8-10$
E. More than $10 \mathrm{t}$

6. How many times has your entrepreneurial team participated in university-enterprise cooperation and exchange activities held by the creation space? (Unit: times)
A. $0-2$
B. 2-4
C. 4-6
D. 6-8
E. More than 8

7. What do you think is the rationality of the organization structure of the creation space management that you work for?

$\begin{array}{lllll}\text { poor } & & & & \text { good } \\ 1 & 2 & 3 & 4 & 5\end{array}$

8. How many patents have your team been granted? (Technical solution, product appearance, etc.)
A. 0
B. 1
C. 2
D. 3
E. More than 8

\section{Appendix 3: Interview Outline of Entrepreneurial Incubation of University the Creation Space}

(I) The researcher briefly introduces himself, research content and research purpose.

(II) Take out the recording equipment, paper and pen, and start recording after obtaining the oral consent of the interviewee.

(III) Ask the interviewees to introduce their personal information and basic information of the enterprise.

(IV) The interview questions are as follows

1. What is the total area of the creation space in Tianjin Polytechnic University at present?

2. How many workplaces can this creation space provide for incubating teams and enterprises at present?

3. How many innovation and entrepreneurship mentors are there in this creation space? How effective is the mentor in guiding the team?

4. Could you please review the number of incubated enterprises or projects since the establishment of the company to the present?

5. May I ask how many service organizations are cooperating with this creation space so far? How is the cooperation going?

6. What is the approximate amount of venture financing and seed fund raised for incubated organizations by the crowd maker space where you work? How is it being used?

7. How many managers are there in your maker space? How many of you have a bachelor's degree or above? What majors are most of them?

8. How much is the policy subsidy fund for this creation space?

End the interview. Stand up and shake hands, thank the interviewee for participating in the study, and say goodbye.

\section{Appendix 4: Assignment Table of Interview Data on Entrepreneurship Incubation of University Creation Space}

Table 8. Quantitative Indicators Eevaluation Table.

\begin{tabular}{|c|c|c|c|c|c|c|c|}
\hline $\begin{array}{l}\text { The serial } \\
\text { number }\end{array}$ & indicators & $\begin{array}{l}\text { The average level of the } \\
\text { creation space in colleges } \\
\text { and universities }\end{array}$ & $\begin{array}{l}50 \%<= \\
(5 \text { points })\end{array}$ & $\begin{array}{l}51 \%-90 \% \\
(5 \text { points) }\end{array}$ & $\begin{array}{l}91 \%-110 \% \\
(5 \text { points) }\end{array}$ & $\begin{array}{l}111 \%-150 \% \\
(5 \text { points) }\end{array}$ & $\begin{array}{l}151 \%>= \\
(5 \text { points })\end{array}$ \\
\hline 1 & Total area of mass innovation space & $1200 \mathrm{~m}^{2}$ & 1 & 2 & 3 & 4 & 5 \\
\hline 2 & Total number of stations provided & 60 & 1 & 2 & 3 & 4 & 5 \\
\hline 3 & Innovation and entrepreneurship mentor team & 12 people & 1 & 2 & 3 & 4 & 5 \\
\hline 4 & Accumulated number of incubated projects & 45 & 1 & 2 & 3 & 4 & 5 \\
\hline 5 & Contracted cooperation agencies & 10 & 1 & 2 & 3 & 4 & 5 \\
\hline 7 & Talent quality structure & $\begin{array}{l}\text { The employment rate of } \\
\text { undergraduates } 100 \%\end{array}$ & 1 & 2 & 3 & 4 & 5 \\
\hline 8 & Total assets of Maker Space & $¥ 3{ }^{\prime} 000 ’ 000$ & 1 & 2 & 3 & 4 & 5 \\
\hline 9 & Number of successful incubators & 10 & 1 & 2 & 3 & 4 & 5 \\
\hline 10 & Policy subsidy & $¥ 500 ’ 000$ & 1 & 2 & 3 & 4 & 5 \\
\hline
\end{tabular}

Note: The average level of mass innovation space in colleges and universities obtained in this paper is derived from the basic background recorded by the creation space in many colleges and universities visited in recent years. Based on the study of relevant references and the communication with experts, this is used as a scoring standard to evaluate the incubation performance of mass innovation space in other colleges and universities. 


\section{References}

[1] Hou Zhenhua, Tang Li, Dong Xiao. Research on the construction of mass innovation space in universities under the background of mass entrepreneurship and innovation $[\mathrm{J}]$. The journal of higher education, 2020 (8): 35-37, 40.

[2] Huang Jiazhen, Xiang Yong, Tan Luwei. Research on entrepreneurship education model of college students based on mass innovation space- Take the provincial college student innovation and entrepreneurship club of Xihua University as an example [J]. Modernization of education, 2019, 6, (26): 27-29.

[3] The Ministry of Education: A third party assessment of higher education. $\quad$ (abstract
[EB/OL] http://www.moe.gov.cn/jyb_xwfb/xw_fbh/moe_2069/xwfbh_2 015n/xwfb_151204/151204_sfcl/201512/t20151204_222891.h tml), 2015-12-04.

[4] Sun Xiaofeng, Mo Xin, Zhu Cuilan. Research on countermeasures for the construction of mass innovation space in colleges and universities [J]. Innovation and entrepreneurship theory research and practice, 2021 (2): 184-187.

[5] Hansen M. T, Chesborough H W, Nohira N, etc. Networked incubators hothouses of the new economy [J]. Harvard Business Review, 2000, 78 (05): 74-84.

[6] Isenberg D J. How to start an entrepreneurship revolution [J]. Harvard Business Review, 2010, 88 (6): 40-50.

[7] Vogel P. The employment outlook for youth: Building entrepreneurship ecosystems as a way forward. Conference Proceedings of the G20 Youth Forum, 2013. 21-23.

[8] Lin Song. Entrepreneurial Ecosystems: Conceptual Development and Operating Mechanisms [J]. Journal of Central University of Finance and Economics, 2011 (04): 58-62.

[9] Wang Youshuang, Gao Xiaowen. Discussion on improving the incubation service capacity of mass innovation space-Take Zidong Creative Space as an example [J]. Jiangsu Science and Technology Information, 2017 (11): 3-6.

[10] Peng Zhansheng, Li Rongjun. A fuzzy comprehensive evaluation model for the incubation capability of science and technology enterprise innovation incubators [J]. Intelligence magazine, 2006 (02): 137-140.

[11] Cai Xiaolin, Huang Haoran, Zheng Jianhua. Research and application of business incubator performance evaluation and promotion methods [J]. Science and Technology Management Research. 2019, 39. (12): 53-57.

[12] Sarfraz A. Mian. Assessing and Managing the University Technology Business Incubator: An Integrative framework. Journal of Business Venturing [J], 2014, 12 (05): 251-285.
[13] Wu Zejun, Tang Houxing. Establishment of evaluation index system for the effectiveness of college students' innovation and entrepreneurship supported by mass innovation space $[\mathrm{J}]$. Journal of Nanchang Institute of Technology, 2017, 36 (2): 88-90.

[14] Li Zhengwei. Performance evaluation of mass innovation space in Suzhou Higher Vocational Colleges [J]. Business Accounting, 2017 (19): 38-41.

[15] Tian Zhongliang, Ren Shaowei. Research on Incubation Mode Construction and Operation Strategy of "Mass Maker Space" in Colleges and Universities. Journal of Anhui University of Technology (Social Science Edition), 2017 (5): 100-102.

[16] Xue Ting. Research on Performance Evaluation System Design of Mass Maker Space in Colleges and Universities [J]. Modern economic information, 2016 (17): 157.

[17] Feng Xinye, Tie Lei. Research on the construction of performance evaluation index system of mass innovation space in Nanchang [J]. Enterprise technology and development, 2018 (12): 205-206.

[18] Wang Mimi, etc. Discussion on the Impact of the Development of Mass Maker Space on the Innovation and Entrepreneurship Ecology of Universities [J]. Information Technology and Informatization, 2016 (4): 125-127.

[19] Wei Yaping. The connotation and operation mechanism of the entrepreneurial ecosystem of "mass innovation space" in colleges and universities $[\mathrm{J}]$. Science and Technology Innovation Review, 2016 (17): 157.

[20] Chen Su, etc. Entrepreneurial Ecosystem of Mass Maker Space: Characteristics, Structure, Mechanism and Strategy [J]. Business Economics and Management, 2015 (11): 35-42.

[21] Wei Yaping, etc. Research on the Docking Path of Entrepreneurship Education and Entrepreneurship Practice [J]. Innovation and Entrepreneurship Education, 2014 (6).

[22] Shen Wei, Yang Lu, Wang Yang, A study on the performance evaluation of innovation space in universities based on AHP, Journal of Zhejiang Wanli University, 2019 (7), 84-89.

[23] Park of tianjin university of technology and guest space to introduce in tianjin university of technology and passenger space intelligent service platform, the network (http://chuangker.Eyw.Edu.Cn/index.ThePHP/Home/index/cat egory/cate/yqjj/p/1.HTML) - 2015.

[24] Xiao Zhixiong, Wang Ran, Investigation on the Development Status of Mass Maker Space in Domestic "Double First-class" Universities [J]. New Century Library, 2019 (06): 93-96.

[25] Chen Qing, Sun Qixin. Research Report on the Development of Mass Maker Space [J]. 2017 (6): 24-27.

[26] Liang Lin, Liu Xiantao. Incubator incubation capability evaluation index system design based on incubation function [J]. Science, Technology and Management, 2005 (4): 28-30. 